\title{
Metastatic Lymph Node Station Number Predicts Survival in Small Cell Lung Cancer
}

Running head: Proposal for revision of $\mathrm{N}$ stage in small cell lung cancer

Han Zhang, $\mathrm{MD}^{1 \#}$, Cong Jiang, $\mathrm{MD}^{1 \#}$, Kaiqi Jing, $\mathrm{MD}^{1}$, Jing Zhang, $\mathrm{MD}^{1}$, Yan Chen, $\mathrm{MD}^{1}$, Yuming Zhu, $\mathrm{MD}^{1}$, Gening Jiang, $\mathrm{MD}^{1}$, Peng Zhang, $\mathrm{MD}, \mathrm{PhD}^{1^{*}}$

${ }^{1}$ Department of Thoracic Surgery, Shanghai Pulmonary Hospital, Tongji University School of Medicine, Shanghai, China

${ }^{\#}$ Han Zhang and Cong Jiang contributed equally to this work.

${ }^{*}$ Correspondence to:

Peng Zhang, Department of Thoracic Surgery, Shanghai Pulmonary Hospital Tongji University, 507 Zhengmin Rd, Shanghai, 200433, P.R. China. Email: zhangpeng1121@tongji.edu.com

Disclosure: The authors declare no conflicts of interest.

\section{Acknowledgments}

Dr. Peng Zhang, Dr Gening Jiang, and Dr. Yuming Zhu contributed equally to the study. This study was supported by the National Natural Science Foundation of China [Grant No. 81972172], the Shanghai Hospital Development Center [Grant No. SHDC12018122], the Shanghai Science and Technology Committee [Grant No. 19XD1423200], and Programs of Shanghai Pulmonary Hospital [No. fkcx1904]. 
medRxiv preprint doi: https://doi.org/10.1101/2020.09.06.20189191; this version posted September 8, 2020. The copyright holder for this preprint (which was not certified by peer review) is the author/funder, who has granted medRxiv a license to display the preprint in It is made available under a CC-BY-NC-ND 4.0 International license .

Words count: 1799

Number of tables: 2; Number of figures: 4; Number of supplementary figures: 1 
medRxiv preprint doi: https://doi.org/10.1101/2020.09.06.20189191; this version posted September 8, 2020. The copyright holder for this preprint (which was not certified by peer review) is the author/funder, who has granted medRxiv a license to display the preprint in It is made available under a CC-BY-NC-ND 4.0 International license .

\section{Abstract (words count: 256)}

2 Purpose: As for pathologic $\mathrm{N}$ category, various regrouping strategies have been raised

3 in non-small cell lung cancer (NSCLC) but little was done in small cell lung cancer

4 (SCLC). On the basis of the suggestions discussed in NSCLC, we proposed a novel,

5 metastatic lymph node station number (MNSN) - based pathologic N parameter and

6 compared its efficacy in predicting survival with $\mathrm{pN}$ in SCLC.

8 Methods: We retrospectively analyzed the patients operated and pathologically

9 diagnosed as SCLC in our hospital between 2009 and 2019. Kaplan-Meier method and

10 Cox regression analysis were used to compare survival between groups defined by $\mathrm{pN}$

11 and MNSN.

13 Results: From 2009 to 2019, 566 patients received surgery for SCLC and 530 of them

14 were eligible for subsequent analysis, with a median follow-up time of 21 months. The

155 -year overall survival (OS) rates were $58.8 \%, 38.6 \%, 27.9 \%$ for $\mathrm{pN} 0, \mathrm{pN} 1, \mathrm{pN} 2$ stages

16 and were $58.8 \%, 36.8 \%, 22.1 \%, 0 \%$ for MNSN0, 1-2, 3-5, 6-7 groups, respectively.

17 Analyses of overall and recurrence-free survival (RFS) revealed that $\mathrm{pN} 1$ could not be

18 distinguished from $\mathrm{pN} 2(\mathrm{OS}, \mathrm{p}=0.099$; $\mathrm{RFS}, \mathrm{p}=0.254)$, but the groups in MNSN were

19 well separated from each other (OS, $\mathrm{p}<0.001, \mathrm{p}=0.001, \mathrm{p}=0.063$; RFS, $\mathrm{p}<0.001$,

$20 \mathrm{p}=0.026, \mathrm{p}=0.01$, compared with the former group). When adjusted for sex, age,

21 smoking, tumor purity and T stage, MNSN groups were independent hazard factors for 
medRxiv preprint doi: https://doi.org/10.1101/2020.09.06.20189191; this version posted September 8, 2020. The copyright holder for this preprint (which was not certified by peer review) is the author/funder, who has granted medRxiv a license to display the preprint in It is made available under a CC-BY-NC-ND 4.0 International license

OS and RFS.

23

24 Conclusions: Based on our cohort study, the MNSN-based N parameter might be a

25 better indicator to predict survival than $\mathrm{pN}$ in SCLC and worth considering in the

26 definition of $\mathrm{N}$ category in the future. 
medRxiv preprint doi: https://doi.org/10.1101/2020.09.06.20189191; this version posted September 8, 2020. The copyright holder for this preprint (which was not certified by peer review) is the author/funder, who has granted medRxiv a license to display the preprint in It is made available under a CC-BY-NC-ND 4.0 International license .

43

44

45

46

47

48

49

50

51

52

53

54

55

56

57

58

59

60 61 combination with $\mathrm{pN}^{21,22}$, et al.

62

63

\section{Introduction}

Lung cancer continues to be the leading cause of morbidity and mortality among all cancers $^{1}$. Especially, SCLC which represents about $15 \%$ of lung cancers has worst prognosis $^{2,3}$. SCLC is characterized by rapid growth rate, early dissemination to regional lymph nodes and distant sites. Although chemotherapy and radiotherapy are recommended for SCLC, the role of surgery still can't be omitted ${ }^{4}$.

In clinical practice of cancers, accurate staging is just second to pathological classifications, which could guide the treatment schemes and predict survival. The staging project for SCLC has shifted from VALG staging system proposed in $1950 \mathrm{~s}^{5,6}$ to TNM staging system in $2009^{7,8}$. However, since the release of seventh edition of the TNM staging system in 2009 , the $\mathrm{N}$ parameter has not been changed in the last decade.

The latest $\mathrm{N}$ parameter recommended by the eighth edition of TNM staging system ${ }^{9}$ is subdivided into N0, N1, N2 and N3 to represent the range of involved lymph node (LN) groups and is identical in SCLC ${ }^{10}$ and NSCLC ${ }^{11}$. In recent years, more and more studies have revealed the heterogeneities in $\mathrm{N} 1$ and $\mathrm{N} 2$ disease $^{12,13}$. Accordingly, several parameters were put forward to regroup N1 or N2 stages in NSCLC, such as the number of positive LNs $(\mathrm{nN})^{14,15}$, the ratio for the number of positive to sampled LNs (LNR) ${ }^{16,17}$, single or multiple-station metastasis ${ }^{18,19}$, presence of skip metastasis ${ }^{11,20}$, and their

Whereas, few studies were carried out to discuss the regrouping strategy of pathologic N stage in SCLC, probably due to the limited number of operated patients. 
medRxiv preprint doi: https://doi.org/10.1101/2020.09.06.20189191; this version posted September 8, 2020. The copyright holder for this preprint (which was not certified by peer review) is the author/funder, who has granted medRxiv a license to display the preprint in It is made available under a CC-BY-NC-ND 4.0 International license .

64 Actually, the staging strategies for LN metastasis used in SCLC were originally

65 proposed in NSCLC and then verified by SCLC database by International Association

66 for the Study of Lung Cancer (IASLC) $)^{8,10}$. Although it was confirmed effective, it may

67 not be ideal considering the difference in cytology, histology and invasiveness between

68 SCLC and NSCLC. Based on the researches in NSCLC, we assumed that metastatic

69 lymph node station number (MNSN) might be related to survival in SCLC.

70 The aim of this study was to verify the efficacy of MNSN in predicting survival in

71 SCLC and compare it with the $\mathrm{pN}$ in eighth edition of TNM staging system.

\section{Materials and methods}

\section{Study Design and Data Source}

74 Patients who underwent pulmonary surgery and were pathologically diagnosed as

75 SCLC in Shanghai Pulmonary Hospital, China from January 2009 to July 2019 were

76 analyzed. Surgeries intended for curative resection with complete mediastinal LN

77 dissection or systematic mediastinal LN sampling were performed. Postoperative

78 chemotherapy with a platin-based regimen was routinely administered except for

79 patients unendurable or refused. Postoperative radiotherapy was administered at the

80 discretion of the radiation oncologists and the suggestion of the referring surgeons.

81 Follow-up was executed by our staff regularly since the discharge from hospital.

82 Exclusion criteria were as follows: (1)Patients with a history of lung cancer; (2)

83 Patients with metastasis; (3) Patients with R1 or R2 resection; (4)Patients without

84 pathologic lymph nodes evaluation for any reasons; (5)Perioperative mortality; (6) 
medRxiv preprint doi: https://doi.org/10.1101/2020.09.06.20189191; this version posted September 8, 2020. The copyright holder for this preprint (which was not certified by peer review) is the author/funder, who has granted medRxiv a license to display the preprint in It is made available under a CC-BY-NC-ND 4.0 International license.

85 Lose contact after being discharged from hospital.

86 The data of SCLC patients in The Surveillance, Epidemiology, and End Results

87 (SEER) database was also used.

\section{Definitions}

Overall survival (OS) is defined as the time between date of surgery and the date of at least one node pathologically confirmed invasion of cancer cells.

\section{Statistical Analysis}

Categorical variables were shown as frequencies and percentages, with $\chi^{2}$ tests 
medRxiv preprint doi: https://doi.org/10.1101/2020.09.06.20189191; this version posted September 8, 2020. The copyright holder for this preprint (which was not certified by peer review) is the author/funder, who has granted medRxiv a license to display the preprint in It is made available under a CC-BY-NC-ND 4.0 International license .

106 probability value less than 0.05 was considered statistically significant. Analyses were

107 performed using Statistical Package for Social Sciences software (SPSS, version 23,

108 IBM Corporation, Armonk, NY).

109 Results

110 Baseline Characteristics

111 From 2009 to 2019, 566 patients were operated and pathologically confirmed SCLC.

112 Among them, 547 patients had LN evaluation. 5 patients with M status, 1 patient with

113 a history of lung cancer, 8 patients died perioperatively and 3 patients losing contact

114 were excluded according to exclusion criteria. Eventually, 530 patients were included

115 in this study (Fig. 1). The average age was $60.7 \pm 9.0$ years, with male making up $87.0 \%$.

116 Video-assisted thoracoscope surgery (VATS) were performed in 268 patients $(50.6 \%)$,

117 in which 100 patients (37.3\%) received uniportal approach (Table 1). The median

118 number of sampled lymph node station was 6 (range 1-11), and the median number of

119 metastatic lymph node station was 1 (range $0-7)$. There were no patients in pathologic

$120 \quad$ N3 stage.

121 MNSN-based LN staging predicts survival ideally

122 To reveal the relationship of MNSN and survival, the Kaplan-Meier method was

123 employed, which showed that patients with greater MNSN had worse OS and RFS

124 (Fig. 2). Meanwhile, some patients with adjacent MNSN shared similar survivals,

125 suggesting the necessity to define groups. Hence, patients were classified into 4-5 
medRxiv preprint doi: https://doi.org/10.1101/2020.09.06.20189191; this version posted September 8, 2020. The copyright holder for this preprint (which was not certified by peer review) is the author/funder, who has granted medRxiv a license to display the preprint in It is made available under a CC-BY-NC-ND 4.0 International license .

126 groups according to the adjacency of MNSN and similarity of survival. Finally, two

127 models were ideal and it could predict both OS and RFS (Fig. 3) when MNSN was

128 classified as $0,1-2,3-5$ and 6-7, four groups. Another grouping strategy was

129 considered unsatisfactory as its less efficacy in predicting RFS, though it performed

130 well in OS (see Supplementary Fig. 1).

131 To balance other hazard factors, sex, age, smoking, tumor purity and pathologic $\mathrm{T}$

132 stage were adjusted in multi-variate COX proportional hazards model, which suggested

133 MNSN group was an independent hazard factor for both OS and RFS (Table 2).

134 MNSN-based N parameter might be better than pN

135 In 2015, the analysis results of IASLC database indicated that $\mathrm{pN}$ in eighth edition

136 of TNM staging system was suitable for SCLC. To compare $\mathrm{pN}$ with MNSN, we also

137 analyzed its discriminatory power for OS and RFS by Kaplan-Meier curve and log-rank

138 test (Fig. 4A-B). Although N0 stage was well distinguished from other stages for OS

139 (N0 vs N1, $\mathrm{p}=0.001$; N0 vs N2, $\mathrm{p}<0.001)$, N1 stage overlapped with N2 stage $(\mathrm{p}=0.099)$.

140 As for RFS, N2 stage also couldn't be separated from N1 stage $(p=0.254)$. The

141 discriminatory power of $\mathrm{pN}$ for N1 and N2 stage in our cohort was similar with it in

142 SEER database (Fig. 4C), in which the survival curves totally overlapped ( $p=0.413$ ).

\section{Discussion}

145 The currently used pathologic $\mathrm{N}$ parameter for lung cancer in 8th edition of TNM 
medRxiv preprint doi: https://doi.org/10.1101/2020.09.06.20189191; this version posted September 8, 2020. The copyright holder for this preprint (which was not certified by peer review) is the author/funder, who has granted medRxiv a license to display the preprint in It is made available under a CC-BY-NC-ND 4.0 International license .

146 staging system was identical to 7 th edition, which was proposed in 2009 and had not

147 been changed thereafter ${ }^{8}$. Though it was validated to be effective in predicting survival,

148 controversies existed as for its discriminatory ability of the N1 and N2 stage.

149 In NSCLC, several studies revealed the heterogeneity in N1 and N2 category ${ }^{23,24}$.

150 Therefore, subdividing of N1 and N2 into more groups was put forward. It was

151 suggested that N1 could be divided into N1a, N1b and N2 could be divided into N2a1,

$152 \mathrm{~N} 2 \mathrm{a} 2, \mathrm{~N} 2 \mathrm{~b}$ according to the number of involved lymph node stations and the presence

153 of skip metastasis. However, analyses of the most updated IASLC lung cancer database

154 indicated the overlap of survival curve in N1b and N2a2, and N2a1 tended to be better

155 than N1b, though not significant. Thus, the IASLC suggested N parameter should be

156 maintained in the 8 th staging system ${ }^{11}$. Other studies recommending the combination

157 of $\mathrm{pN}$ with the number of involved lymph node stations ${ }^{20,25}$ or induction of lymph node

158 ration (LNR) ${ }^{22}$ were worth considering, but should be further validated.

159 In contrast, study of regrouping strategy for pathologic N parameter in SCLC was

160 rare. The IASLC had launched 2 studies evaluating the efficacy of pathologic $\mathrm{N}$

161 parameter in 7th or 8th TNM system in SCLC. The first was carried out in 2009,

162 containing 349 surgical cases in 1990-2000 where pathologic TNM staging was

163 available. In that database, survival curves were separated from each other, though N0

164 overlapped with N1 in the tail, and the median survival time was 51, 24, 13 and 6

165 months for N0 to N3 groups ${ }^{8}$. Differently, the database in 2015 containing 582 patients

166 with adequate pathologic stages in 1999-2009 showed a significant difference between 
medRxiv preprint doi: https://doi.org/10.1101/2020.09.06.20189191; this version posted September 8, 2020. The copyright holder for this preprint (which was not certified by peer review) is the author/funder, who has granted medRxiv a license to display the preprint in It is made available under a CC-BY-NC-ND 4.0 International license.

167 N0 and N1 whereas less difference between N1 and N2 ${ }^{10}$. The disagreement of the 2

168 studies was worth exploring. Since the cases from the later study had no overlap with

169 the former one and were a decade lagging behand, the surgical, pathological and

170 therapeutic improvements may account for the discordance, awaiting more up to date

171 data to verify.

172 In this study, we established a database containing 566 patients who were operated

173 and pathologically confirmed SCLC in our hospital during 2009-2019. Among those

174 patients, 530 were eligible for the evaluation of $\mathrm{N}$ parameter. Consistent with the most

175 updated IASLC database and SEER database, our data showed remarkable difference

176 between N0 and N1 but little even no statistical difference between N1 and N2. By

177 contrast, the metastatic lymph node station number proposed by us was closely related

178 to prognosis. Besides, when MNSN was classified into several groups, it could predict

179 survival better. The result that number of involved lymph node station had preferable

180 predicting value may be explained. The SCLC is a histological subtype characterized

181 by rapid local and distal metastasis. Hence, the location and the distance of regional

182 lymph nodes in SCLC may not be as important as those in NSCLC. Instead, the number

183 of involved lymph node stations which represent the invasiveness and the number of

184 tumor cells to further disseminate distally may play a major role.

185 Some studies nominally referring to the number of involved lymph node stations

186 were actually the combination of location of metastatic nodes, single station versus

187 multiple stations and absence versus presence of skip metastasis ${ }^{15,20,21}$. In other words, 
medRxiv preprint doi: https://doi.org/10.1101/2020.09.06.20189191; this version posted September 8, 2020. The copyright holder for this preprint (which was not certified by peer review) is the author/funder, who has granted medRxiv a license to display the preprint in It is made available under a CC-BY-NC-ND 4.0 International license .

188 to our knowledge, this is the first study which merely use the number of involved lymph

189 node stations independent of node location to predict survival in lung cancer.

190 Accordingly, biases exist in our study including the retrospective nature, the loss to

191 follow-up rate, the rationality of grouping strategy, et al. The median follow-up time is

19221 months in our cohort, which seems to be inadequate. However, considering that the

193 median survival time in SCLC was about 15 months $^{26}$, it is sufficient to observe

194 expected outcomes. Nevertheless, more sophisticatedly designed studies are acclaimed

195 to verify this parameter.

196 In a word, we proposed a novel pathologic $\mathrm{N}$ parameter based on metastatic lymph

197 node station number and it might be a better indicator to predict survival than currently

198 used $\mathrm{pN}$ in SCLC. The reliability of this parameter should be further validated in large-

199 scale, prospective studies. 
medRxiv preprint doi: https://doi.org/10.1101/2020.09.06.20189191; this version posted September 8, 2020. The copyright holder for this preprint (which was not certified by peer review) is the author/funder, who has granted medRxiv a license to display the preprint in It is made available under a CC-BY-NC-ND 4.0 International license .

\section{References}

1. Bray F, Ferlay J, Soerjomataram I, et al: Global cancer statistics 2018: GLOBOCAN estimates of incidence and mortality worldwide for 36 cancers in 185 countries. CA: a cancer journal for clinicians 68:394-424, 2018

2. Navada S, Lai P, Schwartz AG, et al: Temporal trends in small cell lung cancer: Analysis of the national Surveillance, Epidemiology, and End-Results (SEER) database. Journal of clinical oncology : official journal of the American Society of Clinical Oncology 24:7082-7082, 2006

3. Govindan R, Page N, Morgensztern D, et al: Changing epidemiology of smallcell lung cancer in the United States over the last 30 years: analysis of the surveillance, epidemiologic, and end results database. Journal of clinical oncology : official journal of the American Society of Clinical Oncology 24:4539-4544, 2006

4. Shields TW, Higgins GA, Matthews MJ, et al: Surgical resection in the management of small cell carcinoma of the lung. The Journal of thoracic and cardiovascular surgery 84:481-488, 1982

5. Zelen M: Keynote address on biostatistics and data retrieval. Cancer chemotherapy reports. Part 3 4:31-42, 1973

6. Stahel RA, Ginsberg R, Havemann K, et al: Staging and prognostic factors in small cell lung cancer: a consensus report. Lung Cancer 5:119-126, 1989

7. Shepherd FA, Crowley J, Van Houtte P, et al: The International Association for the Study of Lung Cancer lung cancer staging project: proposals regarding the clinical staging of small cell lung cancer in the forthcoming (seventh) edition of the tumor, node, metastasis classification for lung cancer. Journal of thoracic oncology : official publication of the International Association for the Study of Lung Cancer 2:1067-1077, 2007

8. Vallières E, Shepherd FA, Crowley J, et al: The IASLC Lung Cancer Staging Project: proposals regarding the relevance of TNM in the pathologic staging of small cell lung cancer in the forthcoming (seventh) edition of the TNM classification for lung cancer. Journal of thoracic oncology : official publication of the International Association for the Study of Lung Cancer 4:1049-1059, 2009

9. Rami-Porta R, Asamura H, Travis WD, et al: Lung cancer - major changes in the American Joint Committee on Cancer eighth edition cancer staging manual. CA: a cancer journal for clinicians 67:138-155, 2017

10. Nicholson AG, Chansky K, Crowley J, et al: The International Association for the Study of Lung Cancer Lung Cancer Staging Project: Proposals for the Revision of the Clinical and Pathologic Staging of Small Cell Lung Cancer in the Forthcoming Eighth Edition of the TNM Classification for Lung Cancer. Journal of thoracic oncology : official publication of the International Association for the Study of Lung Cancer 11:300-311, 2016

11. Asamura H, Chansky K, Crowley J, et al: The International Association for the Study of Lung Cancer Lung Cancer Staging Project: Proposals for the Revision of the $\mathrm{N}$ Descriptors in the Forthcoming 8th Edition of the TNM Classification for Lung Cancer. 
medRxiv preprint doi: https://doi.org/10.1101/2020.09.06.20189191; this version posted September 8, 2020. The copyright holder for this preprint (which was not certified by peer review) is the author/funder, who has granted medRxiv a license to display the preprint in It is made available under a CC-BY-NC-ND 4.0 International license .

Journal of thoracic oncology : official publication of the International Association for the Study of Lung Cancer 10:1675-1684, 2015

12. Andre F, Grunenwald D, Pignon JP, et al: Survival of patients with resected N2 non-small-cell lung cancer: evidence for a subclassification and implications. Journal of clinical oncology : official journal of the American Society of Clinical Oncology 18:2981-2989, 2000

13. Asamura $\mathrm{H}$, Suzuki $\mathrm{K}$, Kondo $\mathrm{H}$, et al: Where is the boundary between $\mathrm{N} 1$ and N2 stations in lung cancer? The Annals of thoracic surgery 70, 2000

14. Jonnalagadda S, Smith C, Mhango G, et al: The number of lymph node metastases as a prognostic factor in patients with $\mathrm{N} 1$ non-small cell lung cancer. Chest 140:433-440, 2011

15. Lee JG, Lee CY, Park IK, et al: Number of metastatic lymph nodes in resected non-small cell lung cancer predicts patient survival. The Annals of thoracic surgery 85:211-215, 2008

16. Wisnivesky JP, Arciniega J, Mhango G, et al: Lymph node ratio as a prognostic factor in elderly patients with pathological N1 non-small cell lung cancer. Thorax 66:287-293, 2011

17. Qiu C, Dong W, Su B, et al: The prognostic value of ratio-based lymph node staging in resected non-small-cell lung cancer. Journal of thoracic oncology : official publication of the International Association for the Study of Lung Cancer 8:429-435, 2013

18. Lee JG, Lee CY, Bae MK, et al: Validity of International Association for the Study Of Lung Cancer proposals for the revision of $\mathrm{N}$ descriptors in lung cancer. Journal of thoracic oncology : official publication of the International Association for the Study of Lung Cancer 3:1421-1426, 2008

19. Rusch VW, Crowley J, Giroux DJ, et al: The IASLC Lung Cancer Staging Project: proposals for the revision of the $\mathrm{N}$ descriptors in the forthcoming seventh edition of the TNM classification for lung cancer. Journal of thoracic oncology : official publication of the International Association for the Study of Lung Cancer 2:603-612, 2007

20. Park BJ, Kim TH, Shin S, et al: Recommended Change in the N Descriptor Proposed by the International Association for the Study of Lung Cancer: A Validation Study. Journal of thoracic oncology : official publication of the International Association for the Study of Lung Cancer 14:1962-1969, 2019

21. Saji $H$, Tsuboi $M$, Shimada $Y$, et al: A proposal for combination of total number and anatomical location of involved lymph nodes for nodal classification in non-small cell lung cancer. Chest 143:1618-1625, 2013

22. Ding X, Hui Z, Dai H, et al: A Proposal for Combination of Lymph Node Ratio and Anatomic Location of Involved Lymph Nodes for Nodal Classification in Non-Small Cell Lung Cancer. Journal of thoracic oncology : official publication of the International Association for the Study of Lung Cancer 11:1565-1573, 2016

23. Kang $\mathrm{CH}, \mathrm{Ra} \mathrm{YJ}, \mathrm{Kim} \mathrm{YT}$, et al: The impact of multiple metastatic nodal stations on survival in patients with resectable N1 and N2 nonsmall-cell lung cancer. The Annals 
medRxiv preprint doi: https://doi.org/10.1101/2020.09.06.20189191; this version posted September 8, 2020. The copyright holder for this preprint (which was not certified by peer review) is the author/funder, who has granted medRxiv a license to display the preprint in It is made available under a CC-BY-NC-ND 4.0 International license .

of thoracic surgery 86:1092-1097, 2008

24. Shimada $\mathrm{Y}$, Tsuboi M, Saji $\mathrm{H}$, et al: The prognostic impact of main bronchial lymph node involvement in non-small cell lung carcinoma: suggestions for a modification of the staging system. The Annals of thoracic surgery 88:1583-1588, 2009

25. Chen W, Zhang C, Wang G, et al: Feasibility of nodal classification for nonsmall cell lung cancer by merging current $\mathrm{N}$ categories with the number of involved lymph node stations. Thoracic cancer 10:1533-1543, 2019

26. Schabath MB, Nguyen A, Wilson P, et al: Temporal trends from 1986 to 2008 in overall survival of small cell lung cancer patients. Lung Cancer 86:14-21, 2014 
medRxiv preprint doi: https://doi.org/10.1101/2020.09.06.20189191; this version posted September 8, 2020. The copyright holder for this preprint (which was not certified by peer review) is the author/funder, who has granted medRxiv a license to display the preprint in It is made available under a CC-BY-NC-ND 4.0 International license .

Figure legends

Figure 1. Study design. MNSN, Metastatic Lymph Node Station Number; pN, pathologic $\mathrm{N}$ category in TNM staging system

Figure 2. Kaplan-Meier curve for OS (A) and RFS (B) by MNSN. MNSN, Metastatic Lymph Node Station Number

Figure 3. Kaplan-Meier curve for OS (A) and RFS (B) grouped by MNSN. The p value in the graph indicates the significance of log-rank test compared with the upper group. "The difference between MNSN6-7 and MNSN3-5 is not statistically significant, probably due to the small sample capacity in the MNSN6-7 group. OS, overall survival; RFS, recurrence-free survival; 1y-SR, 1-year survival rate, and so on; MNSN, Metastatic Lymph Node Station Number

Figure 4. Kaplan-Meier curve for OS and RFS by the N category in eighth edition of TNM staging system using data from our cohort (A-B) or from the Surveillance, Epidemiology, and End Results database (C). The p value in the graph indicates the significance of log-rank test compared with the upper group. OS, overall survival; RFS, recurrence-free survival; 1y-SR, 1-year survival rate, and so on. 
medRxiv preprint doi: https://doi.org/10.1101/2020.09.06.20189191; this version posted September 8, 2020. The copyright holder for this preprint (which was not certified by peer review) is the author/funder, who has granted medRxiv a license to display the preprint in It is made available under a CC-BY-NC-ND 4.0 International license

Figure 1

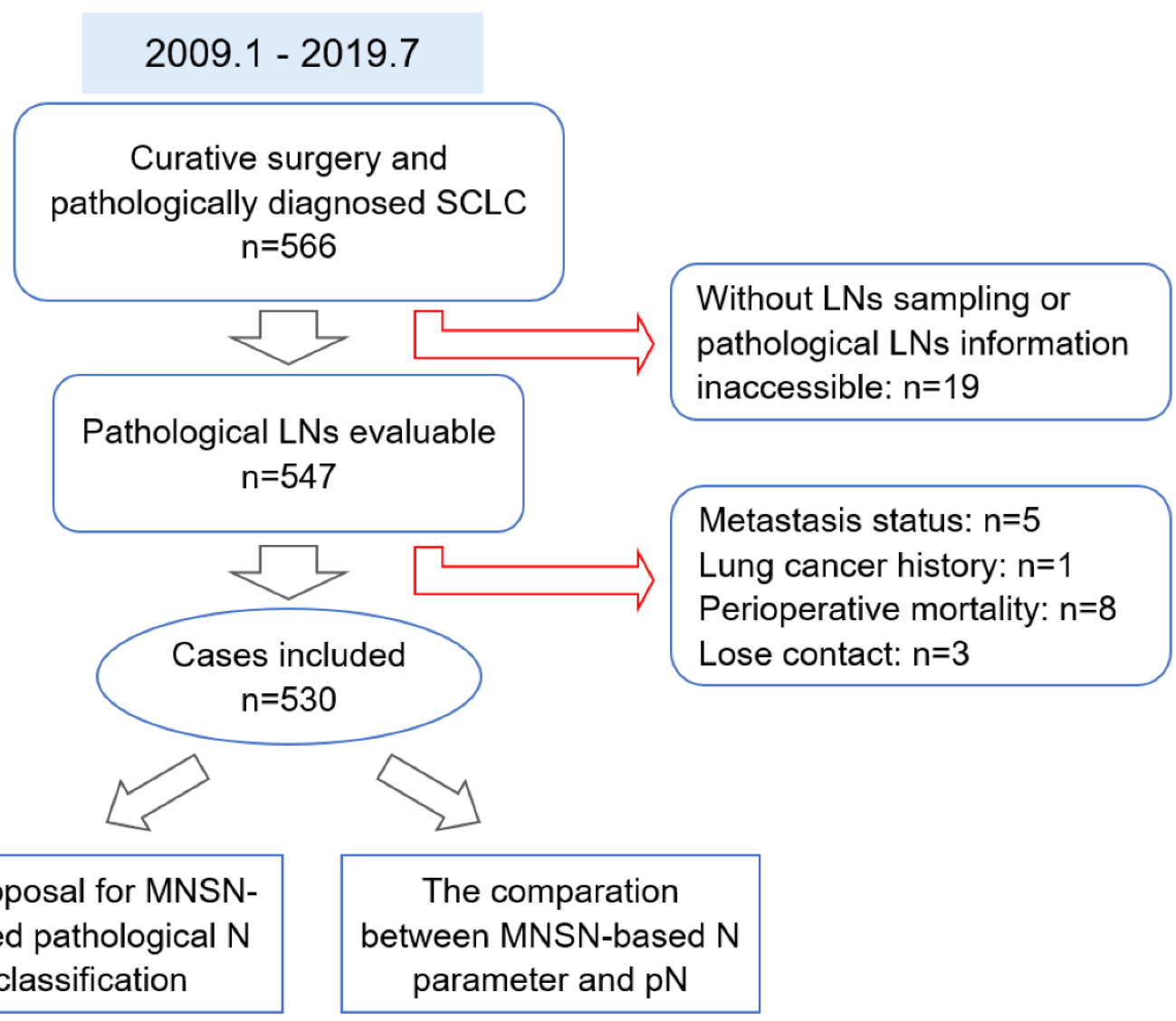


Figure 2
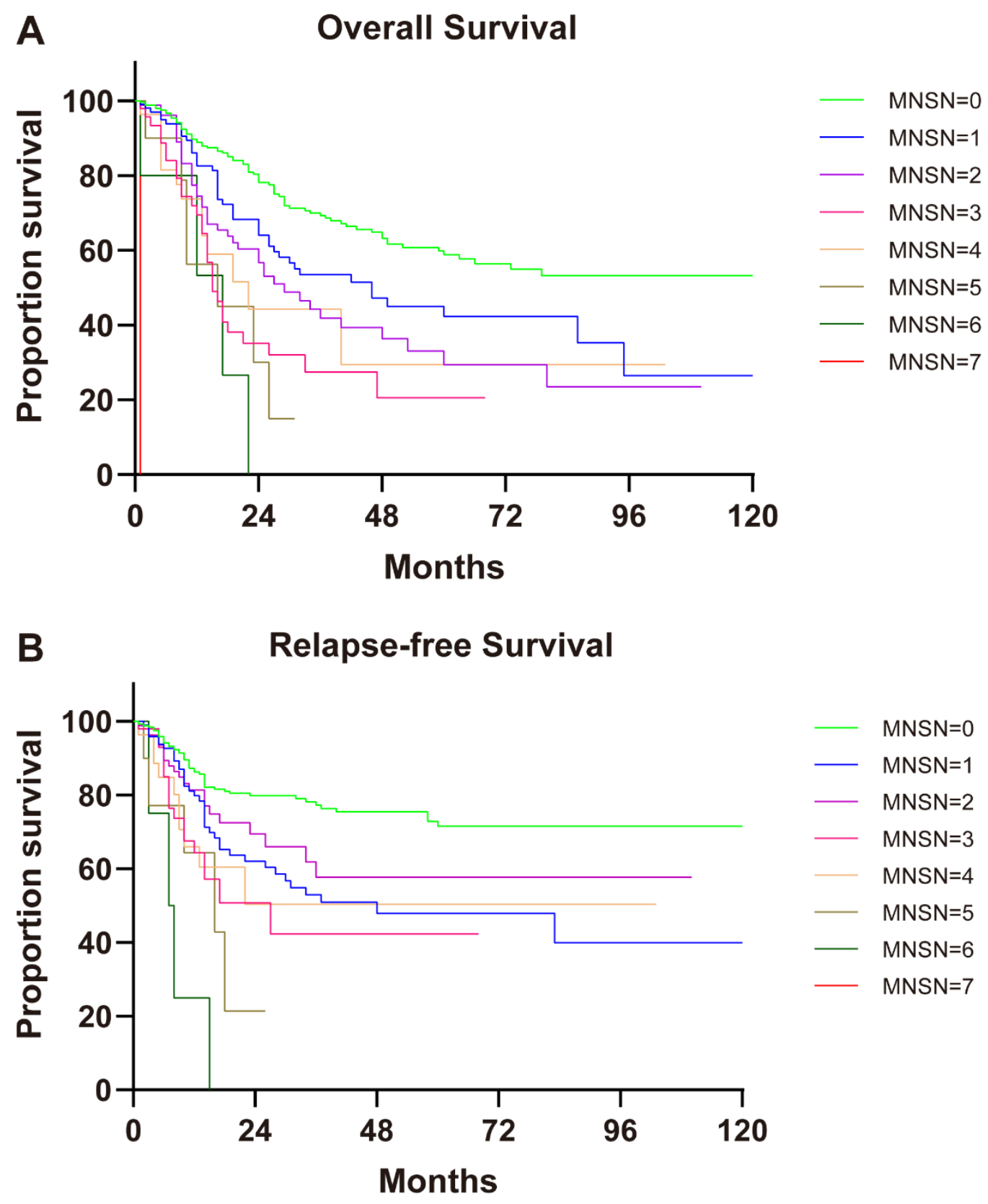

$\mathrm{MNSN}=0$

$\mathrm{MNSN}=1$

$\mathrm{MNSN}=2$

$\mathrm{MNSN}=3$

$\mathrm{MNSN}=4$

MNSN=5

$\mathrm{MNSN}=6$

$\mathrm{MNSN}=7$

Months 
medRxiv preprint doi: https://doi.org/10.1101/2020.09.06.20189191; this version posted September 8, 2020. The copyright holder for this preprint (which was not certified by peer review) is the author/funder, who has granted medRxiv a license to display the preprint in It is made available under a CC-BY-NC-ND 4.0 International license .

Figure 3

A

Overall Survival

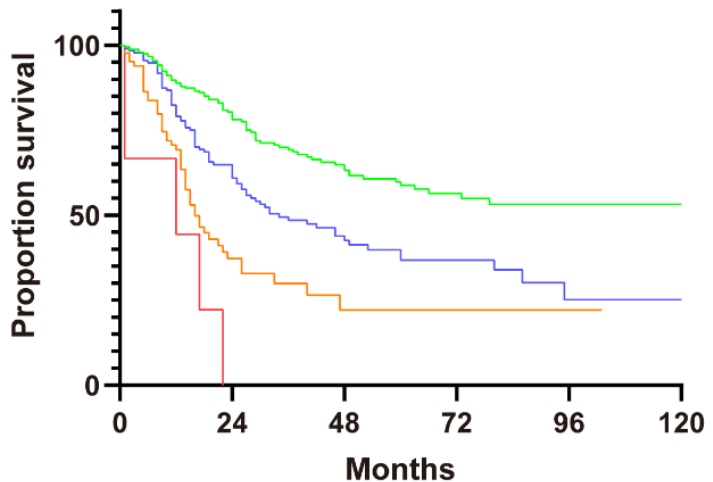

Groups Events / N MST 1y-SR 2y-SR 5y-SR p Value

MNSNO $\quad 78 / 251 \quad$ NR $\quad 89 \% \quad 78 \% \quad 59 \%$

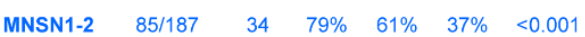

$\begin{array}{lllllll}\text { MNSN3-5 } & 49 / 86 & 16 & 69 \% & 37 \% & 22 \% & 0.001\end{array}$

$\begin{array}{lllllll}\text { MNSN6-7 } & 5 / 6 & 12 & 44 \% & 0 \% & 0 \% & 0.063^{*}\end{array}$

No. at risk

$\begin{array}{lcccccc}\text { MNSN0 } & 251 & 144 & 80 & 39 & 19 & 10 \\ \text { MNSN1-2 } & 187 & 80 & 33 & 16 & 5 & 0 \\ \text { MNSN3-5 } & 86 & 17 & 5 & 1 & 1 & 0 \\ \text { MNSN6-7 } & 6 & 0 & 0 & 0 & 0 & 0\end{array}$

B Relapse-free Survival

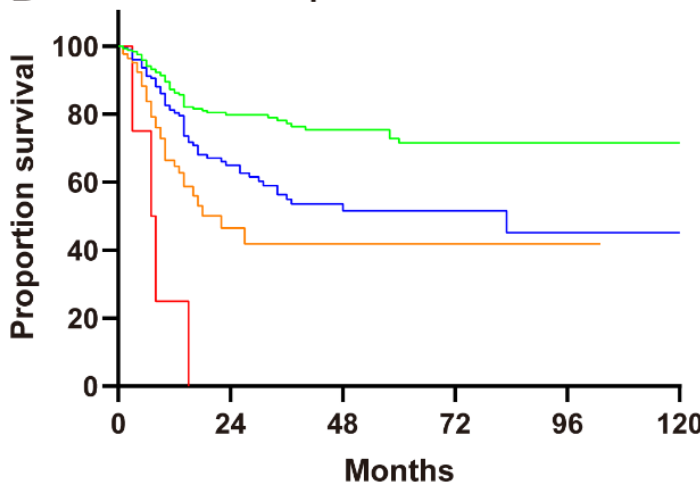

- MNSNO

- MNSN1-2 $(p<0.001)$

MNSN3-5 $(p=0.026)$

- MNSN6-7 $(p=0.01)$

No. at risk

MNSNO

MNSN1-2

Months 
medRxiv preprint doi: https://doi.org/10.1101/2020.09.06.20189191; this version posted September 8, 2020. The copyright holder for this preprint (which was not certified by peer review) is the author/funder, who has granted medRxiv a license to display the preprint in It is made available under a CC-BY-NC-ND 4.0 International license

Figure 4

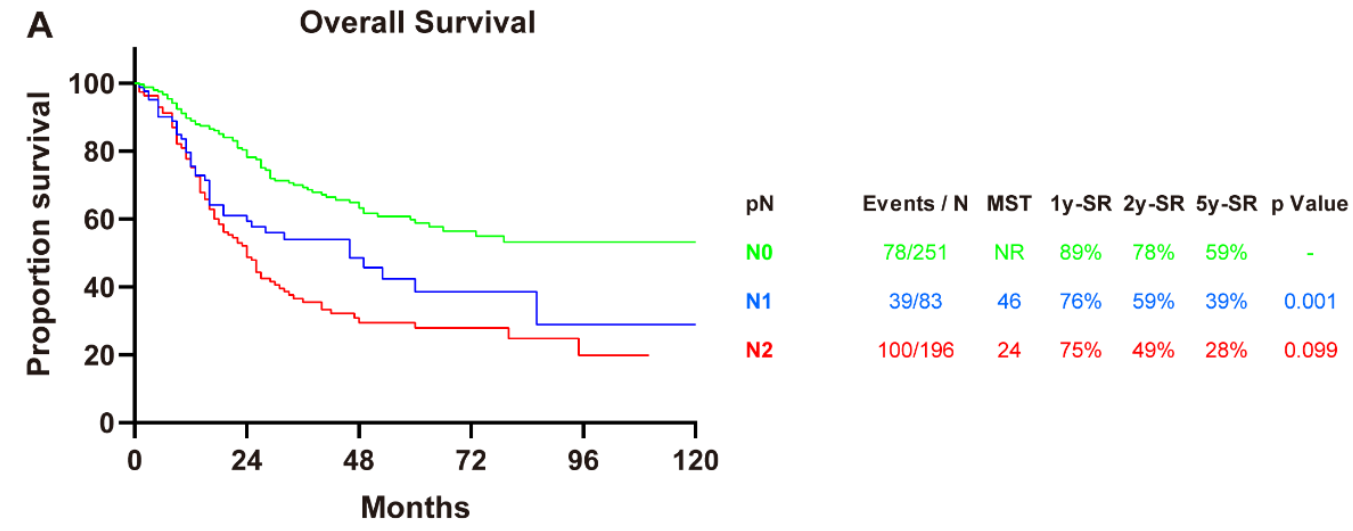

$\begin{array}{lcccccc}\text { No. at risk } & & & & & & \\ \text { N0 } & 251 & 144 & 80 & 39 & 19 & 10 \\ \text { N1 } & 83 & 36 & 17 & 7 & 2 & 0 \\ \text { N2 } & 196 & 61 & 21 & 10 & 4 & 0\end{array}$

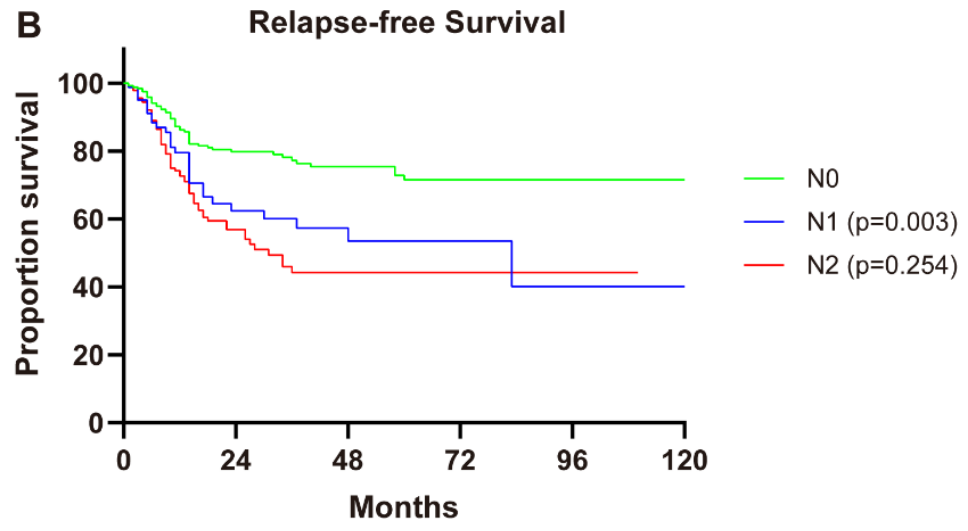

$\begin{array}{lcccccc}\text { No. at risk } & & & & & & \\ \text { N0 } & 251 & 123 & 70 & 35 & 18 & 9 \\ \text { N1 } & 83 & 59 & 14 & 7 & 2 & 0 \\ \text { N2 } & 196 & 42 & 16 & 8 & 4 & 0\end{array}$

\section{Overall Survival}
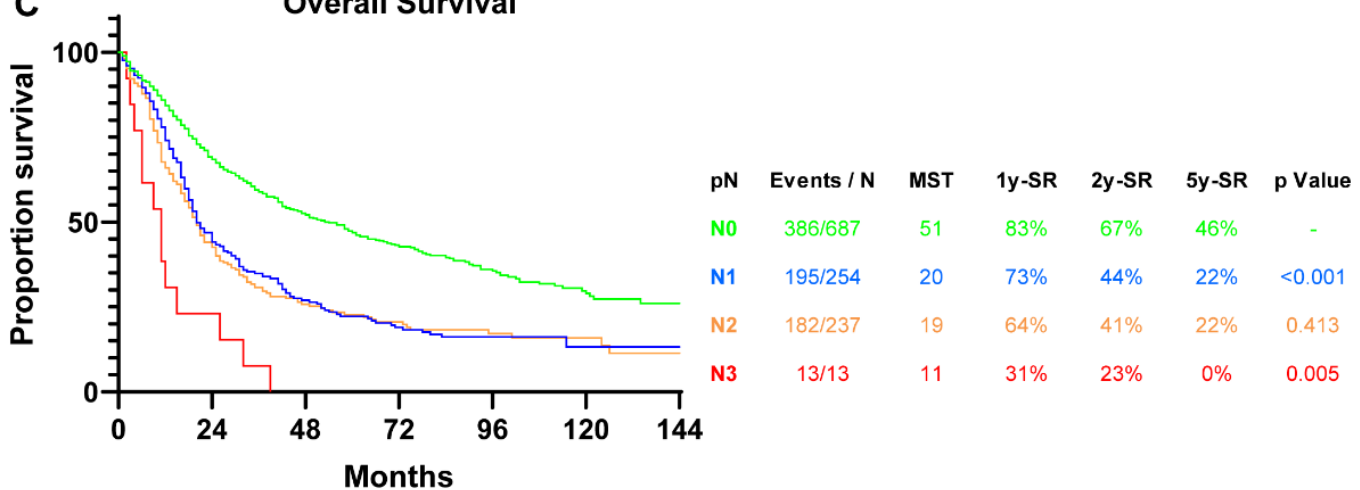

No. at risk

$\begin{array}{lccccccc}\text { N0 } & 687 & 426 & 256 & 168 & 87 & 37 & 9 \\ \text { N1 } & 254 & 105 & 49 & 28 & 20 & 9 & 2 \\ \text { N2 } & 237 & 88 & 44 & 27 & 15 & 8 & 1 \\ \text { N3 } & 13 & 3 & 0 & 0 & 0 & 0 & 0\end{array}$


medRxiv preprint doi: https://doi.org/10.1101/2020.09.06.20189191; this version posted September 8, 2020. The copyright holder for this preprint (which was not certified by peer review) is the author/funder, who has granted medRxiv a license to display the preprint in

It is made available under a CC-BY-NC-ND 4.0 International license .

\section{Table 1. Baseline Characteristics and Pathological Features}

\begin{tabular}{|c|c|c|}
\hline Characteristic & No. & Percentage $(\%)$ \\
\hline Mean Age $(y, \pm S D)$ & $60.7 \pm 9.0$ & \\
\hline \multicolumn{3}{|l|}{ Sex } \\
\hline Male & 461 & 87.0 \\
\hline Female & 69 & 13.0 \\
\hline \multicolumn{3}{|l|}{ Smoking History } \\
\hline Yes & 278 & 52.5 \\
\hline No & 252 & 47.5 \\
\hline \multicolumn{3}{|l|}{ Location } \\
\hline Right Lung & 254 & 47.9 \\
\hline Left Lung & 276 & 52.1 \\
\hline \multicolumn{3}{|l|}{ Extent of pulmonary resection } \\
\hline Sublobar resection & 16 & 3.0 \\
\hline Lobectomy & 353 & 66.6 \\
\hline Bilobectomy & 70 & 13.2 \\
\hline Pneumonectomy & 91 & 17.2 \\
\hline \multicolumn{3}{|l|}{ Means of surgery } \\
\hline Open & 262 & 49.4 \\
\hline VATS & 268 & 50.6 \\
\hline Uniportal & 100 & 37.3 \\
\hline Mean tumor size $(\mathrm{cm}, \pm \mathrm{SD})$ & $3.34 \pm 1.77$ & \\
\hline \multicolumn{3}{|l|}{ T Status } \\
\hline $\mathrm{Tx}$ & 34 & 6.4 \\
\hline $\mathrm{T} 1$ & 206 & 38.9 \\
\hline T1a & 17 & 8.3 \\
\hline $\mathrm{T} 1 \mathrm{~b}$ & 95 & 46.1 \\
\hline T1c & 94 & 45.6 \\
\hline $\mathrm{T} 2$ & 203 & 38.3 \\
\hline $\mathrm{T} 2 \mathrm{a}$ & 156 & 76.8 \\
\hline $\mathrm{T} 2 \mathrm{~b}$ & 47 & 23.2 \\
\hline $\mathrm{T} 3$ & 65 & 12.3 \\
\hline $\mathrm{T} 4$ & 22 & 4.2 \\
\hline Mean No. of LNs resected $( \pm$ SD) & $13.2 \pm 6.5$ & \\
\hline \multicolumn{3}{|l|}{ Histologic subtype } \\
\hline Pure SCLC & 371 & 70.0 \\
\hline Mixed SCLC & 159 & 30.0 \\
\hline \multicolumn{3}{|l|}{ Visceral pleura invasion } \\
\hline Absent & 499 & 94.2 \\
\hline Present & 31 & 5.8 \\
\hline \multicolumn{3}{|l|}{ Nerve invasion } \\
\hline Absent & 521 & 98.3 \\
\hline Present & 9 & 1.7 \\
\hline \multicolumn{3}{|l|}{ Lymphatic vascular invasion } \\
\hline Absent & 482 & 90.9 \\
\hline Present & 48 & 9.1 \\
\hline
\end{tabular}


medRxiv preprint doi: https://doi.org/10.1101/2020.09.06.20189191; this version posted September $8,2020$. The copyright holder for this preprint (which was not certified by peer review) is the author/funder, who has granted medRxiv a license to display the preprint in It is made available under a CC-BY-NC-ND 4.0 International license.
Adjuvant treatment
Chemotherapy
387
73.0
Radiotherapy
152
28.7

SD, standard deviation; VATS, video-assisted thoracoscopic surgery; LN, lymph node; SCLC, small cell lung cancer. 
medRxiv preprint doi: https://doi.org/10.1101/2020.09.06.20189191; this version posted September 8, 2020. The copyright holder for this preprint (which was not certified by peer review) is the author/funder, who has granted medRxiv a license to display the preprint in It is made available under a CC-BY-NC-ND 4.0 International license .

Table 2. Multivariate Cox Proportional Hazards Model Analyses for the Efficacy of MNSN Groups on OS and RFS Adjusted for sex, age, smoking, tumor purity and pathological T stage

\begin{tabular}{|c|c|c|c|c|}
\hline \multirow{2}{*}{ Group } & \multicolumn{2}{|l|}{ OS } & \multicolumn{2}{|l|}{ RFS } \\
\hline & Hazard Ratio $(95 \% \mathrm{CI})$ & $\mathrm{p}$ Value & Hazard Ratio $(95 \% \mathrm{CI})$ & $\mathrm{p}$ Value \\
\hline $\begin{array}{l}\text { MNSN1-2 } \\
\text { vs. MNSN0 }\end{array}$ & $1.923[1.4 .6-2.628]$ & $<0.001$ & $2.014[1.382-2.934]$ & $<0.001$ \\
\hline $\begin{array}{l}\text { MNSN3-5 } \\
\text { vs. MNSN0 }\end{array}$ & $3.785[2.600-5.512]$ & $<0.001$ & 3.194 [2.039-5.004] & $<0.001$ \\
\hline $\begin{array}{l}\text { MNSN6-7 } \\
\text { vs. MNSN0 }\end{array}$ & $7.446[2.946-18.818]$ & $<0.001$ & $11.596[4.143-32.457]$ & $<0.001$ \\
\hline $\begin{array}{l}\text { MNSN3-5 } \\
\text { vs. MNSN1-2 }\end{array}$ & $1.969[1.372-2.826]$ & $<0.001$ & $1.586[1.031-2.440]$ & 0.036 \\
\hline $\begin{array}{l}\text { MNSN6-7 } \\
\text { vs. MNSN1-2 }\end{array}$ & 3.873 [1.541-9.731] & 0.004 & $5.759[2.077-15.963]$ & 0.001 \\
\hline $\begin{array}{l}\text { MNSN6-7 } \\
\text { vs. MNSN3-5 }\end{array}$ & $1.967[0.775-4.992]$ & $0.155^{*}$ & $3.630[1.279-10.305]$ & 0.015 \\
\hline
\end{tabular}

MNSN: Metastatic Lymph Node Station Number; OS, overall survival; RFS, recurrence-free survival; CI, confidence interval.

*The difference between MNSN6-7 and MNSN3-5 is not statistically significant, probably due to the small sample capacity the in the MNSN6-7 group. 